\title{
PENGARUH METODE SUGESTI-IMAJINASI BERBANTUAN MEDIA CARTOON STORY MAKER TERHADAP KEMAMPUAN MENULIS CERPEN
}

\author{
Selviana Kusumawarti Adji*1, Aida Sumardi ${ }^{2}$ \\ ${ }^{1,2}$ Program Studi Pendidikan Bahasa dan Sastra Indonesia, Fakultas Ilmu Pendidikan, \\ Universitas Muhammadiyah Jakarta, Indonesia \\ e-mail: *1 Selviselviana024@gmail.com, ${ }^{2}$ Aidasumardi@gmail.com
}

\begin{abstract}
ABSTRAK
Penelitian ini dilatarbelakangi oleh rendahnya daya imajinasi siswa pada mata pelajaran bahasa indonesia materi Cerita Pendek (Cerpen). Adapun tujuan peneltian ini yaitu untuk mengetahui pengaruh metode sugesti imajinasi berbantuan media cartoon story maker terhadap kemampuan menulis cerpen. Penelitian ini dilaksanakan pada masa pandemik covid 19, sebuah pembelajaran yang dilakukan secara daring pada siswa kelas XI. Sampel pada penelitian yaitu kelas XI IPA 3 sebagai kelas eksperimen dan kelas XI IPA 4 sebagai kelas kontrol. Metode pembelajaran yang digunakan dalam penelitian ini yaitu metode sugesti imajinasi berbantuan media cartoon story maker. Hipotesis penelitian ini menggunakan metode sugesti imajinasi berbantuan media cartoon story maker terhadap kemampuan menulis cerpen berpengaruh lebih baik dibandingkan tanpa menggunakan metode sugesti imajinasi dan media cartoon story maker. Penelitian ini menerapkan metode eksperimen dengan menggunakan true experiment, yaitu sampel yang digunakan pada kelas eksperimen dan kelas kontrol diambil secara acak. Teknik yang digunakan yakni Posttest Only Control Design. Data penelitian diperoleh dari tes menulis. Hasil penelitian menunjukan bahwa metode sugesti imajinasi berbantuan media cartoon story maker dapat berpengaruh pada kemampuan menulis sebuah cerpen siswa kelas XI, sehingga dapat disimpulkan bahwa penggunaan metode sugesti imajinasi berbantuan media cartoon story maker memiliki pengaruh yang signifikan. Hal ini terbukti nilai rata-rata kelas eksperimen sebesar 82,9 dan rata-rata nilai kelas kontrol sebesar 69,9.
\end{abstract}

Kata kunci: metode sugesti imajinasi, media cartoon story maker, menulis cerpen.

\begin{abstract}
The background of this thesis is the students' low imagination of short story writing ability in Indonesian subjects. The purpose of this research is to determine the effect of the imagination suggestion method assisted by the cartoon story maker media on short story writing ability. This research was conducted during the COVID-19 pandemic, an online learning process for class XI . The sample in this study is class XI IPA 3 as the experimental class and class XI IPA 4 as the control class. The learning method used in this research is the imagination suggestion method assisted by cartoon story maker media. The hypothesis of this study using the imagination suggestion method assisted by cartoon story maker media on short story writing ability has a better effect than without using the imagination suggestion method and cartoon story maker media. This study applies an experimental method using a true experiment, namely the samples used in the experimental class and the control class are taken randomly. The technique used is Posttest Only Control Design. The research data was obtained from the writing test. The results showed that the method of imagination suggestion assisted by cartoon story maker media could affect the ability to write a short story for class XI, so it can be concluded that the use of imagination suggestion method assisted by cartoon story maker media had a significant effect. This is proven by the average value of the experimental class of 82.9 and the average value of the control class of 69.9 .
\end{abstract}

Keywords: Imagination Suggestion Method, Cartoon Story Maker Media, and Short Story Writing.

\section{PENDAHULUAN}

Pembelajaran bahasa Indonesia memiliki suatu orientasi atau tujuan tertentu, yaitu meningkatkan keterampilan dalam berbahasa dan bersastra serta meningkatkan kemampuan dalam berfikir dan menalar agar dapat memperdalam wawasan. Selain itu juga diarahkan untuk mengasah perasaan siswa. Siswa juga diharapkan untuk dapat menangkap sebuah informasi yang dapat disampaikan, baik itu secara langsung (sederhana) ataupun yang tidak langsung (tertutup). Dalam proses pembelajaran kurikulum 2013 revisi 2016, Pembelajaran bahasa 
Indonesia melingkupi dengan empat keterampilan yang ada dalam berbahasa ini, diantaranya ialah menulis, membaca, berbicara dan juga menyimak. Menulis adalah suatu tindakan dalam berkomunikasi yang berupa penyampaian suatu informasi ataupun pesan dengan mempergunakan bahasa tulis yang berperan sebagai media atau alatnya. [1] serta suatu cara untuk melepaskan perasaan dan ungkapan diri di dunia pendidikan, siswa yang terbiasa atau gemar menulis akan lebih terampil dan terarah dalam mengekspresikan sebuah ide sehingga secara spontanitas dapat mempertajam kemampuan berfikir. Menurut Sumardi keterampilan menulis dapat dipahami oleh siswa dengan cara memahami konsep dalam menulis serta mempraktikan menulis pada suatu topik.[2] Mardiyah juga menjelaskan bahwa Keterampilan menulis didefinisikan sebagai kegiatan yang dilaksanakan manusia yang secara sadar dan juga terarah dalam menumpahkan, menuangkan dan juga mengekspresikan pengalaman, perasaan, pikiran, gagasan, dan juga ide yang berbentuk dengan suatu yang secara sistematis diorganisasikan dengan mempergunakan kalimat yang logis, dengan demikian hasil tersebut dapat dipahami dengan mudah sejalan dengan orientasi atau tujuan dari penulis itu sendiri [3].

Keterampilan menulis dapat dilakukan dengan menggunakan metode pembelajaran. Salah satunya metode time token arend dapat dikatakan lebih efektif daripada metode mind mapping sehingga hasil belajar yang dicapai peserta didik berbeda [4]. Pada pelajaran Bahasa Indonesia di dalam kurikulum 2013 revisi 2016 untuk kelas XI SMA/SMK/Sederajat, pembelajaran yang menuntut kegiatan menulis cerita pendek terdapat pada kompetensi dasar 4.9.2 yang berbunyi: Menulis cerita pendek dengan cara mencermati berbagai unsur yang membangunnya. Cerita pendek didefinisikan sebagai satu dari berbagai jenis teks narasi yang terdapat dalam kurikulum 2013 pada sistem pengajaran yang saat ini digunakan dalam pembelajaran cerpen tidak lagi membahas kedua unsur cerpen tersebut melainkan sebuah pengajaran sastra dalam bentuk pembelajaran berbasis teks yaitu struktur cerpen itu sendiri, cerpen memiliki sebuah struktur dan struktur tersebut terbagi menjadi 3 yaitu, orientasi, komplikasi, dan resolusi.

Kalau dicermati pembahasan cerpen ini mengarah pada struktur cerpen dan memperketat materi. Pembelajaran serta pengajaran sastra yang berbasis teks ini memiliki tujuan untuk mengajak siswa agar dapat menelaah sebuah teks sastra dalam keadaan ini guru hanya mengarahkan dan menjawab pertanyaan jika ada kesulitan pada siswa. Dengan sebagaimana guru dan siswa akan saling bersaing untuk meningkatkan kemampuan mereka dalam pemberian kesan, pendapat, atau pandagan pada sebuah cerita. Dalam hasil wawancara peneliti dapat mengetahui kendala yang dialami guru saat pembelajaran cerita pendek yaitu kurangnya daya imajinasi siswa dalam menulis cerpen serta kesulitan siswa dalam menentukan dan membuat ide-ide baru untuk menulis cerita pendek.

Depoter mengungkapkan bahwa suggestology atau suggestopedia ini pada dasarnya ialah sugesti imajinasi pasti mampu berpengaruh terhadap hasil dari situasi belajar dan juga menyediakan detail yang menyeluruh, baik itu sugesti negatif dan juga positif [5]. Dalam memberikan sugesti positif ini, terdapat berbagai teknik yang digunakan, diantaranya ialah memerintahkan atau membuat duduk dari para siswa dengan senyaman mungkin, dengan cara memutar musik di dalam ruangan kelas. Dalam hal ini diharapkan penggunaan metode yang efektif dan efisien dapat mempermudah siswa dalam meningkatkan kemampuan keterampilan menulis cerpen, landasan pada metode ini yaitu pemberian sebuah sugesti pada siswa sebagai stimulus serta rangsangan supaya siswa dapat mampu menemukan ide dan gagasan secara cepat dan tepat. Menurut Putu Udiyana juga menjelaskan bahwa Metode sugesti imajinasi ini merupakan suatu metode tertentu di dalam pembelajaran menulis dengan cara memberikan sugesti imajinasi yang dapat memicu imajinasi siswa sehingga siswa dapat menciptakan ide dalam proses pembelajaran yang akan merangsang imajinasi siswa [6].

Maka dari itu peneliti menggunakan media cartoon story maker dalam pembelajaran menulis cerpen agar siswa dapat mengembangkan imajinasi serta menciptakan ide yang akan menjadi sebuah tulisan yaitu cerpen. Penjelasan yang dinyatakan Daryanto mengungkapkan bahwa media yaitu gambaran atau bentuk plural untuk kata Medium yang diartikan sebagai pengatar sebuah hubungan komunikasi tertentu dari pihak yang mengirimkan pesan atau informasi pada pihak yang menerima pesan atau informasi tersebut.[7] Batasan mengenai 
pengertian media dalam pendidikan merupakan sebagai alat dan juga bahan yang berguna untuk aktivitas pembelajaran ini. Hal ini sama dengan pendapat Kuncahyono media yaitu berisikan informasi dan bahan pelajaran yang mempunyai tujuan supaya mempermudah dalam pencapaian sebuah pembelajaran [8].

Menurut Tampi Media ini berbentuk suatu kartun yang sederhana berisikan gambar seri 2D serta melukiskan sebuah percapakan antar tokoh yang terdapat di sebuah cerita. [9] Menurut Riwanto dan Wulandari Cartoon story maker juga merupakan software yang diproduksi oleh Department of Education and Traning State Government of Victoria, Australia. [10] Sedangkan menurut Aulianisa menyebutkan bahwa cartoon story maker adalah sebuah program sederhana yang dapat memungkinkan membuat cerita kartun 2D dan disertakan ilustrasi percakapan dialog.[11] Dengan menggunakan cartoon story maker ini dapat menjadikannya sebagai hal yang cukup menarik untuk dipraktikan sehingga siswa tertarik untuk membuat sebuah cerita supaya dapat meningkatkan kemampuan siswa dalam menulis sebuah cerita serta meningkatkan daya imajinasi siswa.

Cartoon story maker ini mempunyai frame yang ceritanya dapat dilihat satu per satu ataupun dicetak yang memungkinkan siswa untuk lebih mengembangkan imajinasi dan dapat memudahkan siswa untuk berkarya. Kelebihan dari cartoon story maker ini memilki suatu karakter dan background yang tak terbatas serta dapat juga diberikan bentuk rekaman suara. Selain itu media ini memiliki banyak warna yang disertai penggambaran yang unik. Sehingga pembuatan jalan cerita dapat lebih mudah untuk dipahami sehingga mampu memotivasi siswa pada pembelajaran menulis cerpen.

\section{METODOLOGI PENELITIAN}

Metode pada sebuah penelitian dapat didefinisikan sebagai tatacara ilmilah dalam memperoleh data yang tujuan dan serta kegunan yang diharapkan. Metode yang akan dipergunakan dalam pelaksanaan penelitian ini ialah metode penelitian yang bersifat kuantitatif. Penelitian kuantitatif merupakan suatu jenis dari penelitian yang dapat memperoleh temuan atau hasil penelitian yang bisa diproleh dengan prosedur statistik serta cara-cara yang lainnya dari kuantifikasi (pengukuran). Pada penelitian ini dilakukan di SMA Sejahtera 1 Depok dan penelitian ini memperoleh dua variabel. Variabel pertama yaitu variabel independen atau bebas, variabel independen atau bebas merupakan metode sugesti imajinasi berbantuan media cartoon story maker $(\mathrm{X})$ yang diterapkan di kelompok eksperimen kelas IPA3. Variabel kedua yaitu variabel yang berkaitan dengan kemampuan siswa dalam menulis sebuah cerpen (Y) yang diterapkan di kelas kontrol yaitu kelas IPA4. Analisis data dapat dilaksanakan sesudah mendapatkan keseluruhan data pada penelitian, yaitu menggunakan teknik data pengujian $\mathrm{T}, \mathrm{Uji}$ Normalitas, Uji Homogenitas serta Uji Hipotesis.

\section{HASIL DAN PEMBAHASAN}

\section{Hasil Penelitian}

Penelitian dilaksanakan pada SMA Sejahtera 1 Depok pada tanggal 22 sampai 28 Januari 2021. Untuk penelitian ini, sampel penelitian yang digunakan ialah sebanyak 64 peserta didik dari kelas XI IPA 4 dan juga XI IPA 3. Terdapat 32 peserta didik yang berada pada kelas eksperimen, dan kelas kontrol. Aktivitas pembelajaran yang terdapat pada kelas eksperimen ini diberikan perlakuan dengan mempergunakan metode sugesti-imajinasi berbantuan media cartoon story maker, sedangkan kegiatan pembelajaran pada kelas kontrol dengan menggunakan pembelajaran konvensional.

Materi pembelajaran ini dilaksanakan ke dalam dua kali pertemuan dengan zoom dan juga posttest, di setiap tiap-tiap kelas. Posttest didefinisikan sebagai hasil dari tes untuk pengujian penelitian yang paling akhir sesudah diberikan suatu perlakuan tertentu. Tujuan 
penelitian ini ialah untuk mengetahui pengaruh metode sugesti-imajinasi berbantuan media cartoon story maker pada kemampuan menulis cerpen kelas XI.

Sebelum dilakukan perlakuan tes akhir hasil belajar pada siswa, peneliti menggunakan instrumen tes yang sudah divalidasi oleh pihak validator yaitu guru kelas XI. Validator yang dipilih ini ialah sebagai validator yang memiliki profesi bidangnya tersebut, khususnya dalam hal pembelajaran bahasa Indonesia ini.

Nilai hasil belajar siswa didapat setelah diterapkan pembelajaran oleh peneliti dengan memberi suatu perlakuan yang tidak sama terhadap dua kelas tersebut sesuai yang telah ditentukan atau ditetapkan. Kemudian, agar dapat mengidentifikasikan terdapat atau tidak terdapatnya pengaruh terhadap hasil belajar pada kelas kontrol dan juga kelas eksperimen ini, diukur dengan cara pemberian soal menulis cerpen pada siswa dikedua kelas tersebut.

\section{Deskripsi Data Hasil Kelas Eksperimen}

Pada data hasil penelitian di kelas eksperimen yang diberikan perlakuan menggunakan metode sugesti imajinasi berbantuan media cartoon story maker memperoleh nilai yang sudah memenuhi nilai KKM. Nilai KKM pada pembelajaran bahasa Indonesia di SMA Sejahterah1 adalah 75. Adapun hasil nilai menulis cerpen di kelas eksperimen yaitu sebagai berikut.

Tabel 1. Nilai Menulis Cerpen Kelas Eksperimen

\begin{tabular}{|c|c|c|}
\hline No. & Nama & Nilai \\
\hline 1. & ELSC & 81 \\
\hline 2. & HT & 81 \\
\hline 3. & RAS & 77 \\
\hline 4. & LNV & 90 \\
\hline 5. & FRP & 80 \\
\hline 6. & ZBA & 77 \\
\hline 7. & MRS & 77 \\
\hline 8. & PRAK & 82 \\
\hline 9. & $\mathrm{RR}$ & 81 \\
\hline 10. & ARP & 80 \\
\hline 11. & $\mathrm{ABMH}$ & 84 \\
\hline 12. & RSA & 81 \\
\hline 13. & MIR & 82 \\
\hline 14. & MADH & 85 \\
\hline 15. & KRMN & 75 \\
\hline 16. & MAH & 82 \\
\hline 17. & ANW & 85 \\
\hline 18. & NY & 86 \\
\hline 19. & $\mathrm{ABD}$ & 90 \\
\hline 20. & DS & 81 \\
\hline 21. & WP & 75 \\
\hline
\end{tabular}




\begin{tabular}{clc}
\hline No. & Nama & Nilai \\
\hline 22. & RAFA & 82 \\
\hline 23. & IAR & 81 \\
\hline 24. & ZBA & 83 \\
\hline 25. & RMS & 89 \\
\hline 26. & DHW & 82 \\
\hline 27. & THAR & 83 \\
\hline 28. & ARW & 89 \\
\hline 29. & RNA & 76 \\
\hline 30. & KNH & 87 \\
\hline 31. & IG & 80 \\
\hline 32. & SNI & 89 \\
\hline
\end{tabular}

Berdasarkan Tabel 1. memperlihatkan bahwa kemampuan menulis cerpen dari kelas XI IPA 3 sebagai kelas yang diberi suatu perlakuan tertentu dengan mempergunakan metode sugesti imajinasi berbantuan media cartoon story maker, hal ini didapatkan bahwa nilai yang paling tinggi ialah senilai 90 yang diraih siswa ABD, sedangkan untuk nilai yang paling rendah ialah senilai 75 yang diraih siswa WP.

\section{Tabel 2. Data Statistik}

\begin{tabular}{lrr}
\multicolumn{2}{l}{ Kelas Eksperimen } \\
$\mathrm{N}$ & Valid & \\
\cline { 2 - 3 } & Missing & 32 \\
\hline Mean & \\
\hline Median & 82.9375 \\
\hline Mode & 82.0000 \\
\hline Sum & $81.00^{\mathrm{a}}$ \\
\hline
\end{tabular}

a. Multiple modes exist. The smallest value is shown

Berdasarkan pada Tabel 2. hasil tes yang dilaksanakan di kelas eksperimen menggunakan metode sugesti imajinasi berbantuan media cartoon story maker sesuai dengan tabel diatas diperoleh nilai $\mathrm{N}$ sebesar 32 , nilai mean 82.9375 , nilai median 82.000 , nilai mode 81.00 dan sum 2654.00

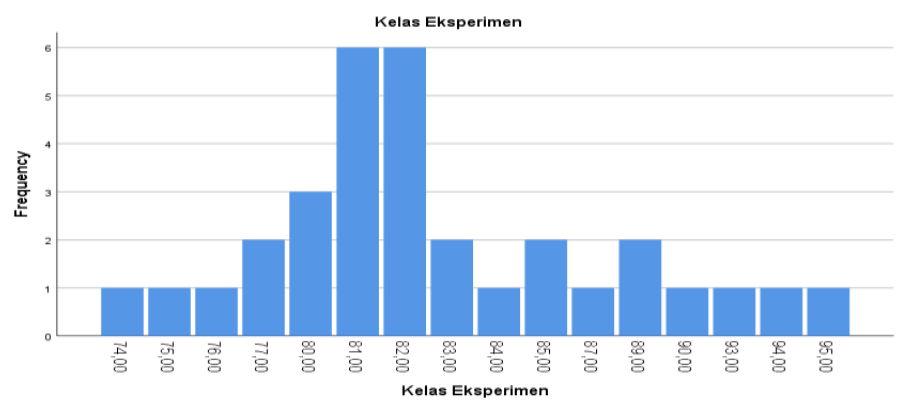

Gambar 1. Grafik Kelas Eksperimen 
Berdasarkan pada Gambar grafik 1, siswa yang mendapat nilai 74-84 ini sejumlah 23 siswa, yang memperoleh nilai 85-90 yaitu sebanyak 9 siswa. Sebanyak 32 siswa yaitu kelas XI IPA3 sebagai kelompok eksperimen yang mendapat perlakukan dalam pembelajaran menulis cerpen dengan mengunakan metode sugesti imajinasi berbantuan media cartoon story maker dengan nilai $74,75,76,84,87,90,93,94$ dan 95 deng frekuensi 1, nilai 77, 83, 85 dan 89 dengan frekuensi 2, nilai 80 dengan frekuensi 3 dan nilai 81 dan 82 dengan frekuensi 6 .

\section{Deskripsi Data Hasil Kelas Kontrol}

Pada data hasil penelitian di kelas kontrol yang tidak diberikan perlakuan menggunakan metode sugesti imajinasi berbantuan media cartoon story maker masih terdapat siswa yang memperoleh nilai di bawah KKM. Nilai KKM pada pembelajaran bahasa Indonesia di SMA Sejahtea 1 adalah 75. Adapun hasil nilai menulis cerpen di kelas kontrol pada Tabel 3. sebagai berikut.

Tabel 3. Nilai Menulis Cerpen Kelas Kontrol

\begin{tabular}{|c|c|c|}
\hline No. & Nama & Nilai \\
\hline $\mathbf{1 .}$ & AN & 71 \\
\hline $\mathbf{2 .}$ & SKA & 70 \\
\hline $\mathbf{3 .}$ & HH & 60 \\
\hline $\mathbf{4 .}$ & TC & 69 \\
\hline $\mathbf{5 .}$ & ANAF & 70 \\
\hline $\mathbf{6 .}$ & IAN & 60 \\
\hline $\mathbf{7 .}$ & FTS & 60 \\
\hline $\mathbf{8 .}$ & AF & 75 \\
\hline $\mathbf{9 .}$ & ZAH & 70 \\
\hline $\mathbf{1 0 .}$ & GDA & 72 \\
\hline $\mathbf{1 1 .}$ & LHS & 73 \\
\hline $\mathbf{1 2 .}$ & LO & 65 \\
\hline $\mathbf{1 3}$. & KBFF & 66 \\
\hline $\mathbf{1 4}$. & ARRP & 70 \\
\hline $\mathbf{1 5}$. & WSA & 68 \\
\hline $\mathbf{1 6}$ & TNY & 75 \\
\hline $\mathbf{1 7}$. & RHD & 75 \\
\hline $\mathbf{1 8}$ & HY & 80 \\
\hline $\mathbf{1 9}$ & ARI & 80 \\
\hline $\mathbf{2 0 .}$ & RAS & 70 \\
\hline $\mathbf{2 1 .}$ & MAW & 60 \\
\hline $\mathbf{2 2 .}$ & MT & 67 \\
\hline $\mathbf{2 3 .}$ & AD & 67 \\
\hline $\mathbf{2 4}$ & FHP & 71 \\
\hline $\mathbf{2 5 .}$ & YEL & 72 \\
\hline & & \\
\hline
\end{tabular}




\begin{tabular}{|c|c|c|}
\hline No. & Nama & Nilai \\
26. & DS & 70 \\
\hline 27. & ASF & 70 \\
\hline 28. & NZN & 75 \\
\hline 29. & FAO & 66 \\
\hline 30. & RFK & 70 \\
\hline 31. & AHO & 70 \\
\hline 32. & MB & 80 \\
\hline
\end{tabular}

Berdasarkan Tabel 3 hasil kemampuan menulis cerpen pada siswa kelas XI IPA 4 sebagai kelas yang tidak diberikan perlakuan menggunakan metode sugesti imajinasi berbantuan media cartoon story maker diketahui bahwa nilai terbesar yaitu 80 yang diperoleh siswa MB,HY, dan ARI. Nilai terkecil yaitu 60 yang diperoleh siswa HH, NZN, IAN dan AN.

Dengan demikian, bisa dihasilkan simpulan bahwa ada sumbangan pengaruh untuk hasil belajar siswa di kelas eksperimen dan kelas kontrol sesuai dengan data yang sudah didapatkan. Dilihat pada nilai kelas eksperimen lebih tinggi dibandingkan nilai dari kelas kontrol yang sebagian nilainya masih di bawah KKM. Hal semacam ini memberikan bukti bahwa kelas yang diberikan perlakukan, ini akan menjadi lebih baik jika diperbandingkan dengan kelas yang tidak diberikan perlakuan.

Tabel 4. Data Statistik

\begin{tabular}{llr}
\hline Kelas Kontrol & \\
& & \\
N $\quad$ Valid & 32 \\
& Missing & 0 \\
Mean & Median & 69.9063 \\
Mode & 70.0000 \\
Sum & 70.00 \\
\hline
\end{tabular}

Berdasarkan Tabel 4 diperoleh nilai $\mathrm{N}$ sebesar 32, nilai mean 69.9063, nilai median 70.000, nilai mode 70.00 dan sum 2237.00. Hal ini menunjukan bahwa kelas eksperimen lebih baik di perlakukan dengan metode sugesti imajinasi berbantuan media cartoon story maker dalam pembelajaran menulis cerpen dibandingkan dengan kelas kontrol yang tidak di beri perlakuan.

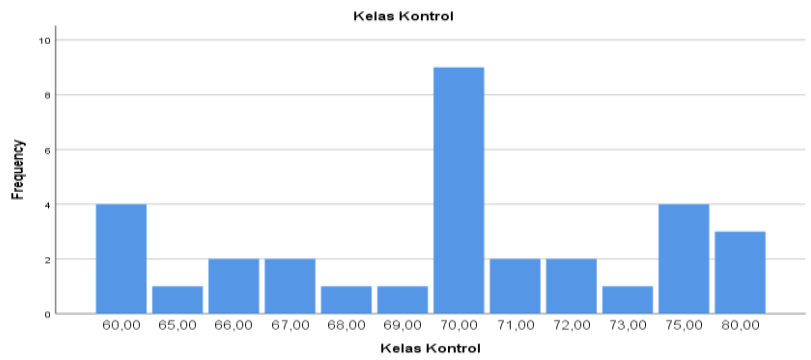

Gambar 2. Grafik Kelas Kontrol

Berdasarkan grafik pada Gambar 2, siswa yang mendapatkan nilai 60-68 sebanyak 5 siswa, yang memperoleh nilai 69-78 yaitu sebanyak 27 siswa. Sebanyak 32 peserta didik yaitu kelas XI IPA 4 yang memainkan peranan sebagai kelas kontrol mendapatkan perlakukan dalam pembelajaran menulis cerpen secara konvensional serta tidak mempergunakan metode sugesti imajinasi berbantuan media cartoon story maker dengan nilai 60 dan 75 dengan frekuensi 4 , 
nilai 65, 68,69 dan 73 dengan frekuensi 1, nilai 66, 67, 71 dan 72 dengan frekuensi 2, nilai 70 dengan frekuensi 9 dan nilai 80 dengan frekuensi 3.

\section{Uji Normalitas Kelas Eksperimen}

Tabel 5. Uji Normalitas Kolmogorov-Smirnov

One-Sample Kolmogorov-Smirnov Test

Kelas

Eksperime

\begin{tabular}{llrr}
\hline $\mathrm{N}$ & & $\mathrm{n}$ \\
\hline Normal & Mean & 32 \\
\cline { 2 - 3 } Parameters $^{\mathrm{a}, \mathrm{b}}$ & Std. Deviation & 82,94 \\
\hline Most & Absolute & 5,186 \\
\cline { 2 - 4 } $\begin{array}{l}\text { Extreme } \\
\text { Differences }\end{array}$ & Positive &, 197 \\
\cline { 2 - 4 } & Negative &, 197 \\
\hline Test Statistic & & &,- 129 \\
\hline Asymp. Sig. & (2-tailed) &, 197 \\
\hline Monte Carlo & Sig. & &, $003^{\mathrm{c}}$ \\
Sig. (2- & 99\% Confidence & Lower Bound &, $147^{\mathrm{d}}$ \\
tailed) & Interval & Upper Bound &, 138 \\
\hline
\end{tabular}

Berdasarkan Tabel 5 uji normalitas yang diperoleh dari 32 siswa dengan diketahui nilai Kolmogorov-Smirnov Test sebesar 0,147 sesuai dengan pengambilan keputusan apabila nilai (Sig. > 0.05) maka dinyatakan normal. Jadi dapat disimpulkan bahwa uji normalitas pada kelas eksperimen dinyatakan berdistribusi normal.

\section{Uji Normalitas Kelas Kontrol}

Tabel 6. Uji Normalitas Kolmogorov-Smirnov

One-Sample Kolmogorov-Smirnov Test

\begin{tabular}{|c|c|c|c|}
\hline \multirow{2}{*}{\multicolumn{3}{|c|}{$\overline{\mathrm{N}}$}} & Kelas Kontrol \\
\hline & & & 32 \\
\hline \multirow{2}{*}{$\begin{array}{l}\text { Normal } \\
\text { Parameter } \\
\mathrm{s}^{\mathrm{a}, \mathrm{b}}\end{array}$} & Mean & & 69,91 \\
\hline & Std. Deviation & & 5,384 \\
\hline \multirow{3}{*}{$\begin{array}{l}\text { Most } \\
\text { Extreme } \\
\text { Differenc } \\
\text { es }\end{array}$} & Absolute & & 163 \\
\hline & Positive & & ,118 \\
\hline & Negative & &,- 163 \\
\hline \multicolumn{3}{|c|}{ Test Statistic } & , 163 \\
\hline \multicolumn{3}{|c|}{ Asymp. Sig. (2-tailed) } &, $030^{\mathrm{c}}$ \\
\hline \multirow{3}{*}{$\begin{array}{l}\text { Monte } \\
\text { Carlo Sig. } \\
\text { (2-tailed) }\end{array}$} & Sig. & &, $326^{\mathrm{d}}$ \\
\hline & $\begin{array}{l}99 \% \text { Confidence } \\
\text { Interval }\end{array}$ & $\begin{array}{l}\text { Lower } \\
\text { Bound }\end{array}$ & ,314 \\
\hline & & $\begin{array}{l}\text { Upper } \\
\text { Bound }\end{array}$ & ,338 \\
\hline
\end{tabular}

Berdasarkan Tabel 6 uji normalitas diperoleh hasil dari 32 siswa dengan nilai Kolmogorov-Smirnov sebesar Sig. 0,326 sesuai dengan pengambilan keputusan apabila nilai 
(Sig. > 0.05) maka dinyatakan normal. Jadi dapat disimpulkan bahwa uji normalitas pada kelas kontrol dinyatakan berdistribusi normal.

\section{Uji Homogenitas Varians}

Untuk memberikan bukti bahwa hasil belajar dari siswa untuk dua sampel penelitian tersebut memiliki variansi yang homogen atau tidak homogen, maka dilaksanakan pengujian homogenitas, kriteria dalam mengambil keputusan untuk pengujian homogenitas ini ialah bila nilai dari signifikansi tersebut lebih tinggi dibandingkan dengan angka 0,05, dengan ini Ha diterima, sementara itu untuk Ho ditolak. Hal ini artinya bahwa adanya pengaruh terhadap penggunaan metode pembelajaran Sugesti-Imajinasi Berbantuan Media Cartoon Story Maker Terhadap Kemampuan Menulis Cerpen Siswa dan dapat dilihat pada tabel berikut.

Tabel 7. Uji Homogenitas

\section{Test of Homogeneity of Variances}

\begin{tabular}{|c|c|c|c|c|c|}
\hline & & $\begin{array}{l}\text { Levene } \\
\text { Statistic }\end{array}$ & df1 & df 2 & Sig. \\
\hline \multirow{4}{*}{$\begin{array}{l}\text { Hasil } \\
\text { Menulis } \\
\text { Cerpen }\end{array}$} & Based on Mean &, 003 & 1 & 62 & ,957 \\
\hline & Based on Median & ,027 & 1 & 62 & ,869 \\
\hline & $\begin{array}{l}\text { Based on Median } \\
\text { and with adjusted } \\
\text { df }\end{array}$ & ,027 & 1 & $\begin{array}{r}62,0 \\
00\end{array}$ &, 869 \\
\hline & $\begin{array}{l}\text { Based on } \\
\text { trimmed mean }\end{array}$ & ,000 & 1 & 62 & ,998 \\
\hline
\end{tabular}

Berdasarkan Tabel 7 hasil diatas uji homogenitas diperoleh nilai 0.957, yang berarti nilai tersebut lebih besar dari 0.05 . Hal ini dapat disimpulkan bahwa varian variabel $(\mathrm{X})$ bersifat homogen. Hal ini berarti adanya pengaruh pada metode Sugesti-Imajinasi Berbantuan Media Cartoon Story Maker Terhadap Kemampuan Menulis Cerpen Siswa.

\section{Uji Hipotesis}

Sesudah data penelitian untuk dua sampel yang didapatkan tersebut dilaksanakan pengujian dengan menggunakan pengujian homogenitas dan juga normalitas. Dengan demikian, data penelitian tersebut dapat dipergunakan untuk menguji hipotesis penelitian tersebut. Tujuan dari pengujian hipotesis ini dilaksanakan untuk meninjau apakah terdapat pengaruh metode Sugesti-Imajinasi Berbantuan Media Cartoon Story Maker terhadap Kemampuan Menulis Cerpen Siswa. Uji hipotesis ini dilakukan dengan menggunakan uji koefisiensi determinasi.

Tabel 8. Uji Hipotesis

\begin{tabular}{|c|c|c|c|c|c|c|}
\hline \multicolumn{7}{|c|}{ ANOVA $^{a}$} \\
\hline \multicolumn{2}{|c|}{ Model } & $\begin{array}{l}\text { Sum of } \\
\text { Squares }\end{array}$ & df & $\begin{array}{l}\text { Mean } \\
\text { Square }\end{array}$ & F & Sig. \\
\hline \multirow[t]{3}{*}{$\overline{1}$} & $\begin{array}{l}\text { Regressio } \\
\mathrm{n}\end{array}$ & 559,116 & 1 & 559,116 & 49,391 &, $000^{\mathrm{b}}$ \\
\hline & Residual & 339,603 & 30 & 11,320 & & \\
\hline & Total & 898,719 & 31 & & & \\
\hline
\end{tabular}

Tabel 9. Hipotesis Uji T 


\begin{tabular}{|c|c|c|c|c|c|}
\hline \multicolumn{6}{|c|}{ Coefficients $^{\mathrm{a}}$} \\
\hline \multirow[b]{2}{*}{ Model } & \multicolumn{2}{|c|}{$\begin{array}{l}\text { Unstandardized } \\
\text { Coefficients }\end{array}$} & \multirow{2}{*}{$\begin{array}{l}\text { Standardi } \\
\text { zed } \\
\text { Coefficien } \\
\text { ts } \\
\text { Beta } \\
\end{array}$} & \multirow[b]{2}{*}{$\mathrm{t}$} & \multirow[b]{2}{*}{ Sig. } \\
\hline & B & Std. Error & & & \\
\hline (Constant) & 1,993 & 9,682 & & ,206 & 838 \\
\hline $\begin{array}{l}\text { Kelas } \\
\text { Eksperimen }\end{array}$ &, 819 &, 117 & ,789 & 7,028 &, 000 \\
\hline
\end{tabular}

Berdasarkan data pada tabel output ANOVA, tabel Uji T pada Tabel 9 dan Tabel 10 Model Summary. Diketahui bahwa nilai signifikansi (Sig.) dalam uji $\mathrm{F}$ adalah sebesar 0,000 , karena Sig. $0,000<0.05$, dan pada uji T nilai signifikansi (Sig.) $0,000<0,05$ maka sebagaimana dasar pengambilan keputusan dalam uji $\mathrm{F}$ dan uji $\mathrm{T}$ yaitu Ha di terima dan Ho ditolak yang berarti bahwa terdapat pengaruh terhadap metode Sugesti-Imajinasi Berbantuan Media Cartoon Story Maker Terhadap Kemampuan Menulis Cerpen. Selanjutnya berdasarkan Tabel 10 output SPSS "Model Summary", diketahui nilai koefisiensi determinasi atau R Square adalah sebesar 0,622.

Tabel 10. Model Summary

\begin{tabular}{ll|r|r|r} 
Model & $\mathrm{R}$ & $\begin{array}{c}\mathrm{R} \\
\text { Square }\end{array}$ & $\begin{array}{c}\text { Adjusted } \mathrm{R} \\
\text { Square }\end{array}$ & $\begin{array}{c}\text { Std. Error of the } \\
\text { Estimate }\end{array}$ \\
\hline 1 &, $789^{\mathrm{a}}$ &, 622 &, 610 & 3,36453 \\
\hline
\end{tabular}

Besarnya koefisien determinasi (R Square) adalah 62,2\%. Angka tersebut mengandung arti bahwa metode sugesti imajinasi berbantuan media cartoon story maker terhadap kemampuan menulis cerpen kelas XI memiliki pengaruh sebesar $62 \%$. Sedangkan sisanya $(100 \%-62 \%=$ $38 \%$ ) dipengaruhi oleh variabel lain di luar persamaan regresi ini atau variabel yang tidak diteliti.

Pada hasil pengujian hipotesis menunjukan adanya pengaruh terhadap metode SugestiImajinasi Berbantuan Media Cartoon Story Maker Terhadap Kemampuan Menulis Cerpen pada kelas XI IPA 3 kelas eksperimen dan XI IPA 4 kelas kontrol SMA Sejahtera 1 Depok.

Sehingga dapat disimpulkan bahwa Uji Hipotesis dalam penelitian ini signifikan atau terdapat pengaruh dibuktikan dengan dalam uji $\mathrm{F}$ dan uji $\mathrm{T}$ adalah sebesar nilai 0,000 , karena Sig. $0,000<0.05$.

\section{Pembahasan}

Pengaruh media cartoon story maker terhadap kemampuan menulis cerpen siswa dapat dikatakan meningkat. Hal ini dapat dibuktikan dengan adanya nilai Sig. 0,000 $<0.05$. maka dapat disimpulkan bahwa media tersebut berpengaruh terhadap kemampuan menulis cerpen siswa. Hal ini juga sejalan dengan penelitian yang menyatakan bahwa media cartoon dapat meningkatkan hasil belajar membaca komprehensif bagi siswa [9].

\section{SIMPULAN}

Hasil perhitungan uji homogenitas menulis cerpen siswa pada kelas XI dapat disimpulkan homogen. Hal ini dibuktikan pada nilai Sig. 0.957, yang mana bahwa nilai ini lebih tinggi diperbandingkan dengan 0.05 dan hasil perhitungan uji $\mathrm{T}$ serta uji $\mathrm{F}$ bahwa nilai signifikansi (Sig.) untuk pengujian $\mathrm{F}$ dan $\mathrm{t}$ ini ialah senilai 0,000, hal ini disebabkan bahwa Sig. 0,000 < 0.05, dengan itu Ha diterima. Dengan demikian bahwa terdapat pengaruh pada penggunaan metode sugesti-imajinasi berbantuan media cartoon story maker terhadap kemampuan menulis cerpen siswa. Penggunaan Metode Sugesti Imajinasi berbantuan media cartoon story maker, terhadap kemampuan menulis cerpen siswa kelas XI dapat meningkatkan daya imajinasi siswa dalam menulis cerpen. Hal ini terbukti pada nilai rata-rata kelas eksperimen ialah senlai 82,9, sementara itu untuk kelas kontrol ialah senilai 69,9. 


\section{REFERENCES}

[1] Dalman, Keterampilan Menulis, 2016, Rajawali Pers, Depok.

[2] A. Sumardi, "Pengaruh Media Kartu Bergambar Untuk Meningkatkan Keterampilan Menulis Narasi Siswa Kelas VII-1 SMP Dharma Karya UT”, J. Penaliterasi, vol. 2, no. 1, pp. 1-7, 2019. Available: http:/jurnal.umj.ac.id/index.php/penaliterasi.

[3] Mardiyah, "Keterampilan Menulis Bahasa Indonesia Melalui Kemampuan Mengembangkan Struktur Paragraf," J. Pendidikan dan Pembelajaran Dasar, vol. 3, no. 2, pp. 1-22, 2016. doi: 0.24042/terampil.v3i2.1188.

[4] Septi Dwi Ernawati, Prasetyo Yuli Kurniawan, \& Ubaedillah. (2019). Keefektifan Metode Time Token Arends Dan Mind Mapping Dalam Menulis Teks Eksposisi. Jurnal Ilmiah SEMANTIKA, 1(1), 55-62. Dapat diunduh pada http://dev.umus.ac.id/index.php/semantika/article/view/82.

[5] B.D Potter dan M. Hemachi, Quantum Learning, 2015, Kaifa, Bandung.

[6] I. A. P. Udiyana, "Pengaruh Metode Sugesti-Imajinasi Dengan Media Foto terhadap Keterampilan Menulis Deskripsi Ditinjau dari Minat Menulis Siswa Kelas VII," J. Ilmiah Pendidikan dan Pembelajaran, vol. 1, no. 1, pp. 78-89, 2017. doi: 10.23887/jipp.v1i1.11964.

[7] Daryanto, Media Pembelajaran, Gava Media, Yogyakarta.

[8] Kuncahyono. "Analisis Penerapan Media Berbasis Komputer pada Pembelajaran Tematik Terpadu di Sekolah Dasar", J. Pemikiran dan Pengembangan SD, vol. 5, no. 2, pp. 773780, 2017. doi: https://doi.org/10.22219/jp2sd.v5i2.

[9] Y. Tampi, "Implementasi Media Cartoon Story Maker dengan Model Pembelajaran Langsung untuk Meningkatkan Reading Comprehension Siswa Kelas IXA SMP 1 Tamiang Layang," J. Bahasa, Sastra dan Pembelajaran, vol. 4, no. 1, pp. 123-135, 2014. Available: https://ppjp.ulm.ac.id/journal/index.php/jbsp/article/view/3796.

[10] M. A. Riwanto dan M. P. Wulandari, "Efektivitas Penggunaan Media Komik Digital (Cartoon Story Maker) dalam pembelajaran Tema Selalu Berhemat Energi," J. PANCAR, vol. 2, no. 1, pp. 15-18, 2018. Available: https://ejournal.unugha.ac.id/index.php/pancar/article/view/195.

[11] Aulianisa, N. T, "Menjelajahi aplikasi Cerita Kartun sebagai Media Instruksional dalam Menulis Teks Naratif di SMA." J. JOEPALLT, vol. 7, no. 01, pp.1-14, 2019. Available: https://jurnal.unsur.ac.id/jeopallt/article/view/540. 